\title{
Properties of NADPH-Cytochrome P-450 Reductase Purified from Rabbit Liver Microsomes ${ }^{1}$
}

\author{
JOHN S. FRENCH² AND MINOR J. COON \\ Department of Biological Chemistry, Medical School, The University of Michigan, \\ Ann Arbor, Michigan 48109
}

Received December 12, 1978; revised February 20, 1979

\begin{abstract}
NADPH-cytochrome $P-450$ reductase has been purified to electrophoretic homogeneity from rabbit liver microsomes by a procedure that may be used in conjunction with the isolation of the major forms of cytochrome $P-450$. The purified reductase is active in a reconstituted hydroxylation system containing $P-450 \mathrm{LM}_{2}$ or $P-450 \mathrm{LM}_{4}$. The enzyme contains one molecule each of FMN and FAD per polypeptide chain having an apparent minimal molecular weight of 74,000. Immunological techniques provided evidence for only a single form of the reductase; lower molecular weight forms occasionally seen are believed to be due to degradation by contaminating microsomal or bacterial proteases. Upon anaerobic photochemical reduction, the rabbit liver reductase undergoes spectral changes highly similar to those previously deseribed by Vermilion and Coon for the rat liver enzyme; the fully reduced rabbit liver enzyme is converted to the three-electron-reduced form by the addition of NADP and then to the stable one-electron-reduced form by exposure to oxygen. The CD spectra of the fully oxidized enzyme, one-electron-reduced form (air-stable semiquinone), three-electron-reduced form, and fully reduced form are presented. The results obtained provide evidence that the FMN and FAD are in highly different environments in the enzyme, as also indicated by the different redox potentials and oxygen reactivities of the flavins.
\end{abstract}

Earlier studies in this laboratory on the resolution from rabbit liver microsomes of the enzyme system which hydroxylates fatty acids, steroids, and a variety of drugs and other compounds indicated that detergent-solubilized NADPH-cytochrome $P-450$ reductase ${ }^{3}$ retained the ability to transfer electrons to $P-450 \mathrm{LM}_{4}(1-3)$. In contrast, the enzyme purified from lipase- or proteasetreated microsomes and usually called NADPH-cytochrome $c$ reductase (4-7) was

1 This research was supported by Grant PCM7614947 from the National Science Foundation and Grant AM-10339 from the United States Public Health Service.

${ }^{2}$ Predoctoral Trainee of the United States Public Health Service, Training Grant GM-00187. The data in this paper are taken from a thesis submitted in partial fulfillment of the requirements for the degree of Doctor of Philosophy in Biological Chemistry in the Rackham School of Graduate Studies at the University of Michigan. Present address: Department of Biochemistry, University of California, Berkeley, Calif. 94720.

${ }^{3}$ Systematic name, NADPH:ferricytochrome $P-450$ oxidoreductase, EC 1.6.2.4. incapable of reducing cytochrome $P-450$ and therefore of functioning in the reconstituted hydroxylation system $(2,3,8)$. NADPHcytochrome $P-450$ reductase has previously been partially purified from rabbit liver microsomes in this laboratory $(3,9)$ and purified from rat liver microsomes to electrophoretic homogeneity in both this and other laboratories (10-13).

The present paper is concerned with the isolation and characterization of the reductase from rabbit liver microsomes. The availability of the highly purified reductase as well as two forms of cytochrome $P-450$ $(14,15)$ from a single source will permit more meaningful studies on the interactions of these enzymes in the reconstituted system (16). While this paper was in preparation, Iyanagi et al. (17) reported the extensive purification and some of the properties of the rabbit liver reductase. The reductase is unusual in containing both FMN and FAD, as first reported for trypsin-solubilized preparations (18) and confirmed for the de- 
tergent-solubilized enzyme purified from both rat $(10-13)$ and rabbit liver microsomes $(9,17)$.

\section{EXPERIMENTAL PROCEDURES}

Purification of rabbit liver microsomal enzymes. $P-450 \mathrm{LM}_{2}{ }^{4}$ and $P-450 \mathrm{LM}_{4}$ were purified from liver microsomes of phenobarbital-induced rabbits by methods devised in this laboratory $(9,14,15,19,20)$, including a fractionation step with polyethylene glycol which results in precipitation of the cytochromes and leaves NADPH-cytochrome $P-450$ reductase in the supernatant fraction. The reductase may be further purified from this supernatant fraction or isolated directly from microsomes with omission of polyethylene glycol treatment. The procedures described below are similar to those already reported for the isolation of the reductase from phenobarbital-induced rat liver microsomes $(10$, $12,13)$, including affinity chromatography with the use of ADP-agarose (11).

The purification steps summarized in Table I were carried out at $4^{\circ} \mathrm{C}$, and all buffer solutions contained $10 \%$ glycerol and $0.1 \mathrm{~mm}$ EDTA and were at $\mathrm{pH} 7.7$ (measured at $4^{\circ} \mathrm{C}$ ) unless stated otherwise. Tris buffer was the chloride salt and phosphate buffer the potassium salt. The preparations were stored at $4^{\circ} \mathrm{C}$, and after removal of excess nonionic detergent by calcium phosphate gel treatment the enzyme was also stable to storage in the frozen state. Exposure of the reductase preparations to light was avoided where possible, especially in the presence of ammonium sulfate, which causes loss of FMN (21). Protein concentrations were estimated according to Lowry et al. (22) with correction for the effect of other components of the solutions (15); bovine serum albumin served as the standard.

Liver microsomes were isolated from phenobarbitaltreated, male New Zealand rabbits and extracted with pyrophosphate buffer as described elsewhere (15). The pyrophosphate-treated microsomes, which were stored at $-20^{\circ} \mathrm{C}$ in Tris-acetate buffer in the presence of $20 \%$ glycerol (9), were thawed, solubilized with cholate, and fractionated with polyethylene glycol under conditions previously described (15). The precipitates were used for further purification of $P-450 \mathrm{LM}$, and the $12 \%$ polyethylene glycol supernatant fraction was used for isolation of the reductase. This fraction, in $500-\mathrm{ml}$ batches, was brought to $25 \%$ saturation in ammonium

${ }^{4}$ Abbreviations used: $P$-450LM, liver microsomal cytochrome $P-450$; dilauroyl-GPC, dilauroylglyceryl-3phosphorylcholine; IgG, immunoglobulin G; SDS, sodium dodecyl sulfate. The various forms of $P-450 \mathrm{LM}$ are numbered according to their relative electrophoretic mobilities; $P-450 \mathrm{LM}_{2}$ is the form induced by phenobarbital, and $P-450 \mathrm{LM}_{4}$ is a form present in both untreated and phenobarbital-treated animals and increased to about twice as high a level by induction with 5,6-benzoflavone. sulfate by addition of the solid salt over about $30 \mathrm{~min}$ with stirring. The mixture was centrifuged for $10 \mathrm{~min}$ at $8000 \mathrm{~g}$, and the supernatant layer containing the polyethylene glycol was removed by aspiration and discarded. The enzyme solution was made $10 \mu \mathrm{M}$ in FMN and put onto a Bio-Gel P-6 column $(5 \times 50 \mathrm{~cm})$ previously equilibrated with $0.05 \mathrm{M}$ Tris buffer solution containing $0.01 \%$ sodium azide, followed by 2 liters of the same solution. The desalted protein, which was eluted in a broad, reddish brown band clearly separated from free flavin, was stored at $-20^{\circ} \mathrm{C}$. Four or five such preparations were thawed, made $0.4 \%$ in Renex 690 by the addition of a $10 \%(\mathrm{w} / \mathrm{v})$ solution of the detergent, and applied to a DEAE-cellulose column by a slight modification of a previous procedure (13). Those fractions with NADPH-cytochrome $c$ reductase activity were treated with calcium phosphate gel, and the enzyme solution in $0.15 \mathrm{M}$ phosphate buffer containing $0.1 \%$ Renex was applied to a column of ADP-agarose (11, 13). The reductase was eluted with deoxycholatephosphate buffer solution containing $2.0 \mathrm{~mm} \mathrm{2}$-AMP. Those fractions having the spectral properties of the reductase (as described below) were pooled, omitting a heme-containing fraction at the front of the peak. The preparation was adsorbed on calcium phosphate gel and eluted with $0.15 \mathrm{~m}$ phosphate buffer. The eluate, which was dialyzed overnight against 1 liter of $50 \mathrm{~mm}$ Tris or phosphate buffer, was the purified reductase preparation used in the studies to be described unless otherwise indicated. A small amount of enzyme remaining bound to the column may be eluted with NADP as described below (ef. Fig. 3).

For isolation of the reductase from pyrophosphateextracted microsomes without recovery of $P-450 \mathrm{LM}$, solubilization was accomplished with Renex at a protein to detergent ratio of $1: 1$ by the procedure of Dignam and Strobel (23) as modified by Vermilion and Coon (13). Fractionation with polyethylene glycol was omitted, and the Renex extract was diluted 1.5-fold with water and submitted directly to DEAE-cellulose column chromatography.

Enzymatic assays. The reductase was assayed routinely by its ability to catalyze cytochrome $c$ reduction in $0.3 \mathrm{M}$ phosphate buffer, $\mathrm{pH} 7.7$, at $30^{\circ} \mathrm{C}$ (5). The reaction was initiated by the addition of the reductase, and the rate of cytochrome $c$ reduction was determined at $550 \mathrm{~nm}$ using an extinction coefficient of $21 \mathrm{~mm}^{-1}$ $\mathrm{cm}^{-1}(24)$ for the conversion of the oxidized cytochrome to the reduced form. One unit of enzyme is defined as the amount which catalyzes the reduction of $1.0 \mu \mathrm{mol}$ of the cytochrome/min under these conditions, and specific activity is defined as units per milligram of protein. NADPH oxidation in the presence of saturating amounts of $P-450 \mathrm{LM}$, phospholipid, and benzphetamine was used as a measure of the ability of the reductase to transfer electrons to its physiological acceptor in the reconstituted enzyme system. The reaction mixture contained the following components, added in the order indicated: $0.5 \mathrm{nmol}$ of $P-450 \mathrm{LM}, 50 \mu \mathrm{g}$ of dilauroyl-GPC, 
varying amounts of reductase, $50 \mu \mathrm{mol}$ of Tris buffer, $\mathrm{pH} 7.5$, and $1.0 \mu \mathrm{mol}$ of benzphetamine, in a final volume of $1.0 \mathrm{ml}$. The mixture was incubated at $30^{\circ} \mathrm{C}$ for $3 \mathrm{~min}$, and the reaction was initiated by the addition of $0.15 \mu \mathrm{mol}$ of NADPH. The oxidation of NADPH was followed at $340 \mathrm{~nm}$ at $30^{\circ} \mathrm{C}$ with a Beckman DU spectrophotometer equipped with a Gilford Model 2000 multiple sample absorbance recorder. Turnover numbers were calculated using an extinction coefficient of $6.22 \mathrm{~mm}^{-1} \mathrm{~cm}^{-1}$ at $340 \mathrm{~nm}$ for NADPH and the experimentally determined extinction coefticient of 21.4 $\mathrm{mM}^{-1} \mathrm{~cm}^{-1}$ at $456 \mathrm{~nm}$ for measuring the concentration of the reductase. In some cases $\mathrm{N}$-demethylation was assayed by determining radioactive formaldehyde produced from $[N-$ methyl-14 $\mathrm{C}]$ benzphetamine (25). The rates reported for the reconstituted system are in all cases corrected for controls with $P-450 \mathrm{LM}$ omitted.

Amino acid analysis. Protein samples for amino acid analysis were dialyzed to remove glycerol, concentrated, and hydrolyzed for 24,48 , or $72 \mathrm{~h}$ in constantboiling $\mathrm{HCl}$ in evacuated, sealed tubes. The amino acids were analyzed using a modified Beckman $120 \mathrm{~B}$ amino acid analyzer with the Durram single column system and $\mathrm{DC}-1 \mathrm{~A}$ resin and Pico system $I I$ buffers. The values for serine and threonine were corrected for decomposition with time. Total half-cystine was determined as cysteic acid after hydrolysis of the protein in the presence of dimethyl sulfoxide as described by Spencer and Wold (26). Sulfhydryl titrations were carried out with 5,5'-dithiobis(2-nitrobenzoate) as described by Ellman (27) using the extinction coefficients in the presence and absence of guanidine determined by Gething and Davidson (28). Tryptophan was determined after hydrolysis of the protein by methane sulfonic acid (29) and separation on Beckman AA15 resin, or by titration of the enzyme with $N$-bromosuccinimide ( 30$)$.

Spectral determinations. Reductase samples in 0.05 M Tris buffer, $\mathrm{pH} 7.5$, containing $10 \%$ glycerol and $5 \mathrm{~mm}$ EDTA, were placed in a Thunberg anaerobic cuvette with four polished sides and two side arms. Absorption spectra were recorded with a Varian Cary 219 recording spectrophotometer using a path length of $10 \mathrm{~mm}$ for the visible region and $4 \mathrm{~mm}$ for the ultraviolet region. CD spectra were recorded using a 4-mm path length with a Jasco $40 \mathrm{C}$ spectropolarimeter equipped with a Tracor Northern TN1500 digital signal analyzer and a Data General Nova 3 computer. By use of anaerobic techniques described elsewhere (31), the enzyme was photoreduced under nitrogen in the presence of 5-deazaflavin (3,10-dimethyl-5-deazaisoalloxazine) and EDTA according to the procedure of Massey and Hemmerich (32). The samples were immersed in an ice-water bath during irradiation with light from a Smith-Victor "sungun" operated at $70 \mathrm{~V}$ at a distance of $7 \mathrm{~cm}$. All spectra were recorded at $12^{\circ} \mathrm{C}$.

Materials. Unlabeled $d$-benzphetamine and pregnenolone carbonitrile were generously provided by $\mathrm{Dr}$. P. W. O'Connell of the Upjohn Co., $\left[N-m e t h y l-{ }^{14} \mathrm{C}\right]-$ benzphetamine by Dr. A. Y. H. Lu of Hoffmann-La Roche, Inc., and Arochlor by Dr. L. S. Kaminsky of the New York State Department of Health; Renex 690 (polyoxyethylene[10]nonylphenylether) was donated by the Atlas Chemicals Division of ICI America and deazaflavin by Dr. Vincent Massey. Bio-Gel P-6 was obtained from Bio-Rad, and 5,5'-dithiobis(2-nitrobenzoate) and $N$-bromosuccinimide were from Sigma. Other materials $(9,13)$ and the procedures for preparation and washing calcium phosphate gel and DEAEcellulose were as described previously (3).

\section{RESULTS}

\section{Purity and Properties of NADPH-cyto- chrome P-450 Reductase}

The results of a typical experiment on the purification of the reductase are shown in Table I. The procedure, which is based in

\section{TABLE I}

Purification of NADPH-CyTochrome $P$-450 Reductase From Rabit Liver Microsomes ${ }^{a}$

\begin{tabular}{|c|c|c|c|c|c|c|c|c|}
\hline \multirow[b]{2}{*}{ Preparation } & \multicolumn{4}{|c|}{ Reductase purified in conjunction with $P-450 \mathrm{LM}$} & \multicolumn{4}{|c|}{ Reductase purified without recovery of $P-450 \mathrm{LM}$} \\
\hline & $\begin{array}{l}\text { Volume } \\
\text { (ml) }\end{array}$ & $\begin{array}{l}\text { Protein } \\
\text { (mg) }\end{array}$ & $\begin{array}{l}\text { Specific activity } \\
\text { (units/mg protein) }\end{array}$ & $\begin{array}{l}\text { Yield } \\
(\%)\end{array}$ & $\begin{array}{l}\text { Volume } \\
\text { (ml) }\end{array}$ & $\begin{array}{l}\text { Protein } \\
\text { (mg) }\end{array}$ & $\begin{array}{l}\text { Specific activity } \\
\text { (units/mg protein) }\end{array}$ & $\begin{array}{l}\text { Yield } \\
(\%)\end{array}$ \\
\hline $\begin{array}{l}\text { Pyrophosphate-treated microsomes } \\
\text { Cholate-solubilized preparation; } \\
12 \% \text { polyethylene glycol super- } \\
\text { natant fraction; Bio-Gel P-6 } \\
\text { column eluate }\end{array}$ & 2,500 & 17,500 & $0.4(0.3-0.6)$ & 100 & 800 & 8,000 & $0.3(0.3-0.5)$ & 100 \\
\hline $\begin{array}{l}\text { DEAE-cellulose column eluate } \\
\text { (0.4\% Renex); calcium phosphate } \\
\text { gel eluate } \\
\text { ADP-Agarose column eluate; } \\
\text { ( } 0.1 \% \text { Renex, } 0.1 \% \text { deoxycholate); } \\
\text { calcium phosphate gel eluate }\end{array}$ & 20 & 490 & $7.0(5.0-13.0)$ & 49 & 40 & 300 & $7.3(5.0-11.0)$ & 91 \\
\hline
\end{tabular}

${ }^{\alpha}$ The values given in parentheses indicate the range of specific activities obtained in a series of such experiments. 
part on those previously reported for the purification of the reductase from rat liver microsomes $(10-13)$, yields homogeneous rabbit liver microsomal reductase while allowing for concurrent purification of $P-450 \mathrm{LM}$. However, the yield of the reductase is about twice as great when the polyethylene glycol step is omitted with no attempt to recover the cytochrome fraction, and in this case the specific activity is usually higher, probably

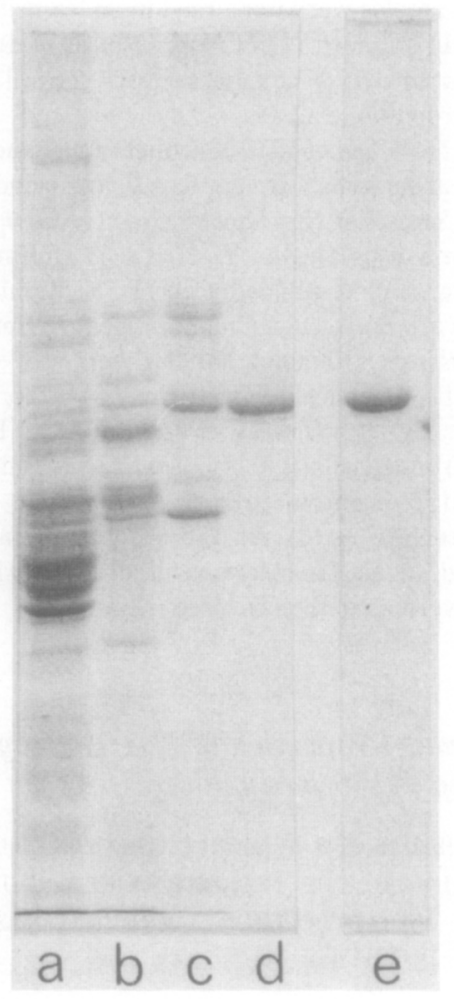

FIG. 1. SDS-polyacrylamide slab gel electrophoresis of reductase at various stages of purification. Migration was from top to bottom. The samples were boiled in the presence of SDS and $\beta$-mercaptoethanol (15), and a $20-\mu l$ aliquot of each solution was applied to a gel containing $7.5 \%$ acrylamide and submitted to electrophoresis according to the method of Laemmli (33). The preparations from a typical purification experiment (corresponding to those in Table I) and amounts of protein were as follows: $a$, phenobarbitalinduced, pyrophosphate-treated microsomes $(8.0 \mu \mathrm{g})$; $b$, Bio-Gel P-6 column eluate of $12 \%$ polyethylene glycol supernatant fraction ( $4.0 \mu \mathrm{g})$; $c$, DEAE-cellulose column eluate $(2.0 \mu \mathrm{g})$; and $d, \mathrm{ADP}$-agarose column eluate $(0.5 \mu \mathrm{g})$. Preparation $e(0.5 \mu \mathrm{g})$ was similar to $d$ but had a higher specific activity and exhibited a single electrophoretic band. because of the presence of less flavin-depleted reductase. We have found that the rabbit reductase is particularly sensitive to proteolysis, but that with care one can avoid the production of degradation products during the purification procedure. The necessary precautions include rapid, careful handling of the microsomes and crude extracts, avoidance of bacterial growth by including $0.01 \%$ sodium azide during the early fractionation steps, and sterilization of the purified enzyme by passage through a Millipore filter (pore size, $0.45 \mu$ ).

Analysis of the enzyme preparations at various stages of purification by SDS-polyacrylamide gel electrophoresis following treatment with SDS and $\beta$-mercaptoethanol gave the results shown in Fig. 1. The final preparations eluted from the ADP-agarose column usually exhibit a single major band and traces of other bands, whereas the best preparations are electrophoretically homogeneous. In other experiments this band was shown to correspond in mobility to a molecular weight of 74,000 , as indicated by comparison with standard proteins. It may be noted that, whereas the reductase is dissociated into polypeptide chains by SDS treatment, the isolated enzyme exists as an aggregate of apparent molecular weight $500,000(16)$.

A typical pattern for elution of the reductase from the DEAE-cellulose column is shown in Fig. 2. The eluate was divided into fractions, as indicated, and submitted to SDS-polyacrylamide gel electrophoresis as shown in the inset to the figure. Fractions $b, c$, and $d$ appeared to be largely free of proteins other than the reductase, whereas the other fractions contained a small amount of the reductase and predominantly other proteins. It may be noted that Fractions $c$, $d, e$, and sometimes portions of $b$ and $f$ are ordinarily used for further fractionation, thereby accounting for a yield of greater than $90 \%$ at this step. Some analytical data on these fractions, including catalytic activities, are given in Table II. The FMN content of Fractions $c$ and $d$, as compared to the theoretical value of $13.5 \mathrm{nmol} / \mathrm{mg}$ of protein for an enzyme of 74,000 molecular weight, suggests that such reductase preparations are about $35 \%$ pure. The cytochrome $c$ re- 


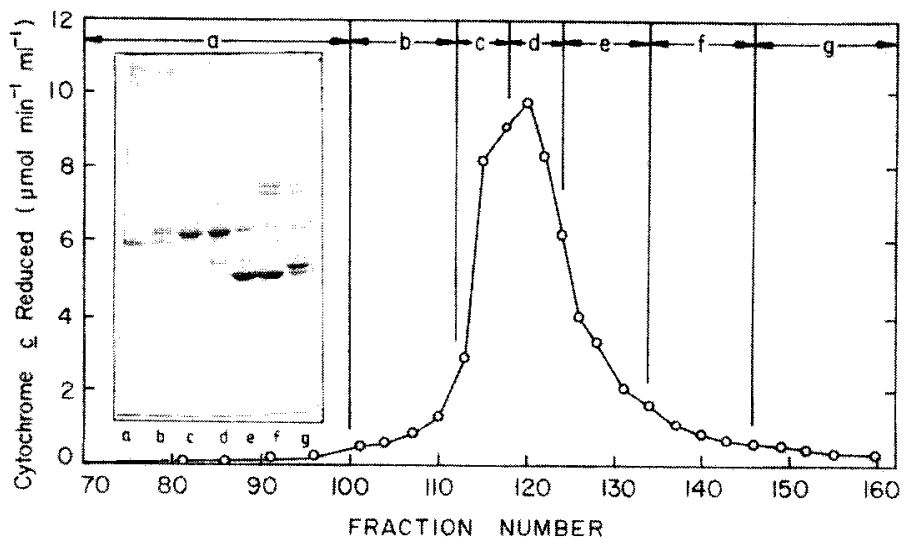

Fig. 2. Elution pattern of reductase from DEAE-cellulose column with increasing $\mathrm{KCl}$ concentration. The eluate was pooled to give seven fractions, as indicated. Each fraction was treated with calcium phosphate gel, washed, and eluted as described under Experimental Procedures. The inset shows the electrophoretic patterns when the pooled fractions ( $2 \mu \mathrm{g}$ of protein each) were submitted to SDSpolyacrylamide gel electrophoresis after treatment with calcium phosphate gel.

ductase turnover numbers, although slightly low, are relatively constant across the elution profilc. In contrast, the $P-450 \mathrm{LM}_{2}$-dependent activities are unexpectedly low in the least pure fractions. This decreased activity is seen in both the rates of NADPH oxidation and formaldehyde formation. In a further experiment, when the reductase was removed from Fraction $b$ or $f$ and the remaining material was added to a system reconstituted from purified reductase and $P-450 \mathrm{LM}_{2}$, inhibition was seen. The results obtained upon ADP-agarose column chromatography of the reductase are given in Fig. 3. Following elution of the enzyme by $2 \mathrm{mM} 2$ '-AMP, a $0.5 \mathrm{~mm}$ solution of NADP was put onto the column to remove the residual yellow protein, and a small second peak of reductase appeared. In experiments not presented, similar results were obtained when the reductase was eluted from an ADP-agarose column first with NADP and then with 2 -AMP. In each instance the small second peak represented roughly $15 \%$

TABLE II

Properties of Fractions Eluted from DeAE-Cellulose Columa ${ }^{a}$

\begin{tabular}{cccccc}
\hline & & & \multicolumn{2}{c}{ Apparent turnover number } \\
\cline { 4 - 5 } Fraction & $\begin{array}{c}\text { Protein } \\
\text { concentration } \\
(\mathrm{mg} / \mathrm{ml})\end{array}$ & $\begin{array}{c}\text { FMN } \\
\text { concentration } \\
\text { (nmol/mg protein) }\end{array}$ & $\begin{array}{c}\text { Cytochrome } c \\
\text { as acceptor }\end{array}$ & PADPH oxidation & HCHO formation \\
\hline b & 1.83 & 1.5 & 2700 & 30 & 10 \\
c & 1.44 & 4.7 & 3300 & 56 & 25 \\
d & 1.90 & 5.1 & 3400 & 60 & 26 \\
e & 2.43 & 1.2 & 3400 & 44 & 18 \\
f & 2.73 & 0.6 & 2900 & 24 & 11 \\
\hline
\end{tabular}

a The turnover numbers were calculated using the FMN content, determined fluorimetrically (13,34), as a measure of the reductase concentration. The assay procedures with cytochrome $c$ and with $P-450 \mathrm{LM}_{2}$ in the presence of benzphetamine are given under Experimental Procedures. 


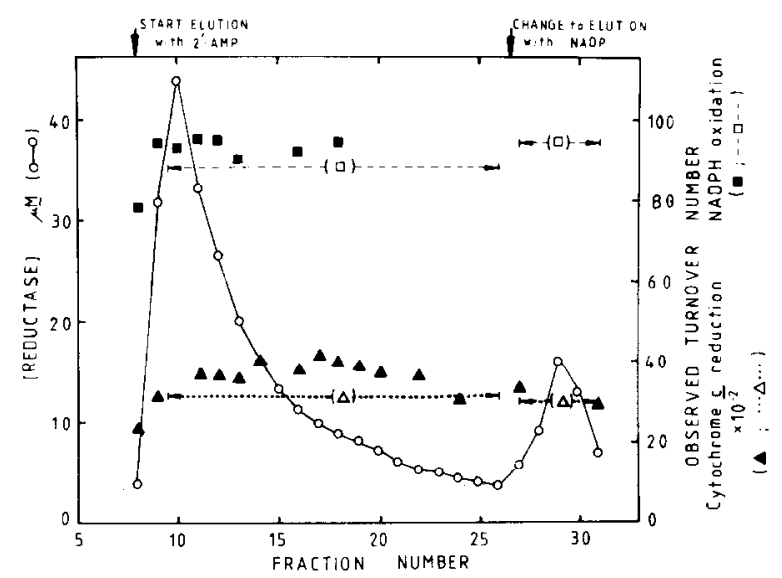

FIG. 3. Elution pattern of reductase from ADP-agarose column. The activities of the individual fractions resulting from $2^{\prime}$-AMP and NADP elution are shown as follows: cytochrome $c$ reduction $(\mathbf{A})$ and $P-450 \mathrm{LM}_{2}$ reduction ( $\square$ ). The samples eluted with 2 -AMP and NADP were pooled separately, treated with calcium phosphate gel (as described in the text), and assayed for cytochrome $c$ reduction $(\triangle)$ and $P-450 \mathrm{LM}_{2}$ reduction ( $\square$ ) açtivities.

of the total reductase. Since the reductase samples in the two peaks have identical electrophoretic behavior (data not shown) and highly similar catalytic activities as indicated in the figure, it is probable that they represent a single form of the enzyme and may possibly result from differences in the ligand environments in the ADP-agarose.

Evidence that the purified rabbit liver reductase is electrophoretically homogeneous as judged by the SDS-polyacrylamide gel technique has already been presented. Such enzyme preparations were analyzed for their content of several components, with the results shown in Table III. Nearly equimolar amounts of FAD and FMN were found, with the latter at a slightly lower level in some reductase preparations. The flavin content is consistent with the high purity of the enzyme. Iron was not detected in significant amounts by atomic absorption spectrometry, although a trace of heme is occasionally evident in the spectrum of the purified reductase upon reduction. Analysis for carbohydrate revealed no sugar residues except for a single pentose accounted for by the FAD present; control experiments showed that an authentic sample of FAD gave the same colorimetric effect. Phospholipid and deoxycholate were not present in the reductase preparations at levels suffi- ciently high to be detected with assurance, and Renex could not be detected by the cobalt ammonothiocyanate method $(39,40)$.

The spectrum of the purified reductase

TABLE III

ANALYSIS OF REDUCtase IsOlated from RABBIT LIVER MICROSOMES ${ }^{a}$

\begin{tabular}{lc}
\hline Component & $\begin{array}{c}\text { Concentration } \\
(\mathrm{nmol} / \mathrm{nmol} \text { of polypeptide })\end{array}$ \\
\hline FAD & $0.84-0.96$ \\
FMN & $0.78-0.94$ \\
Iron & $<0.07$ \\
Carbohydrate & 0.96 \\
Phospholipid & $<0.2$ \\
Deoxycholate & $<0.07$ \\
\hline
\end{tabular}

${ }^{a}$ Flavins were determined as described in detail previously (13); the values given are an average of those obtained by fluorimetric methods involving the effect of $\mathrm{pH}$ (34) and of Naja naja venom. Iron was determined with a Perkin-Elmer Model 306 atomic absorption spectrometer using reagent grade iron wire dissolved in nitric acid as the standard. Carbohydrate was assayed by the phenol-sulfuric acid method according to Dubois et al. (35), and deoxycholate by the method of Masbach et al. (36). Phospholipids were extracted and ashed as described by Chen et al. (37), and the phosphorus content of the residues was determined according to Bartlett (38). 


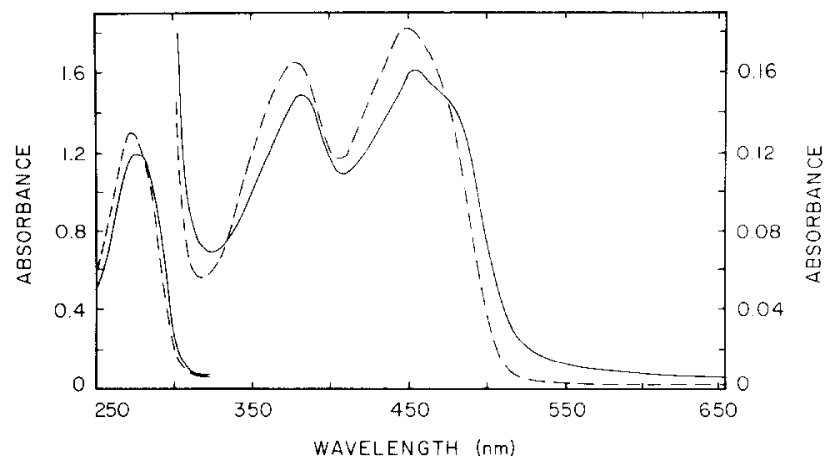

FIG. 4. Spectral changes upon denaturation of reductase by guanidine. The reductase $(8.7 \mathrm{nmol}$ in $1.0 \mathrm{ml}$ of $50 \mathrm{~mm}$ Tris buffer, $\mathrm{pH} 7.5$ ) was placed in one side of a tandem cell, and the same volume of $8 \mathrm{~m}$ guanidine hydrochloride (also buffered to $\mathrm{pH} 7.5$ with $50 \mathrm{~mm}$ Tris) was placed in the other side. The reference cell contained buffer and $4 \mathrm{M}$ guanidine, so as to correct for the small absorbance of the latter compound. The spectrum of the native reductase (solid line) was recorded, the solutions in the tandem cells were mixed, and the spectrum of the denatured enzyme (dashed line) was recorded after $90 \mathrm{~min}$. The light path was $0.875 \mathrm{~cm}$. As indicated in the figure, the spectrum in the visible region was recorded at ten times greater sensitivity than in the ultraviolet region.

before and after treatment with $4 \mathrm{M}$ guanidine is shown in Fig. 4. The content of free flavin in several such denatured preparations, estimated spectrophotometrically using the experimentally determined extinction coefficient of $11.9 \mathrm{~mm}^{-1} \mathrm{~cm}^{-1}$ at $450 \mathrm{~nm}$ (per flavin) for an equimolar mixture of FMN and $\mathrm{FAD}$ in $4 \mathrm{M}$ guanidine at $\mathrm{pH} 7.5$, was found to be in good agreement with the values obtained by fluorimetric methods. The extinction coefficients for the native enzyme, based on the flavin content, were calculated to be $21.4,19.5$, and $159 \mathrm{mM}^{-1} \mathrm{~cm}^{-1}$ at 456 , 382 , and $277 \mathrm{~nm}$, respectively. The $A_{277} / A_{456}$ ratio for the rabbit liver reductase is 7.4 as compared with 8.7 for the rat liver reductase (13) and 6.7 and 6.3 for the rat liver enzyme solubilized by treatment with bromelain (41) or trypsin (42), respectively. The minimal molecular weight of the rabbit liver microsomal reductase was estimated from the flavin content to be 77,000 ; this figure is in reasonable agreement with the value of 78,000 reported by Iyanagi et al. (17) and 74,000 determined by calibrated SDS-polyacrylamide gel electrophoresis in the present study.

Immunochemical evidence was also obtained for the homogeneity of the reductase preparation. Antibodies were elicited to the purified rabbit liver enzyme in goats by the general procedure used previously with cytochrome $P-450$ (43), and Ouchterlony double diffusion experiments were carried out with IgG purified from the resulting antiserum. In such experiments not shown, samples of the purified reductase were placed in wells surrounding a center well containing antibody. Only single precipitin bands with no spurs were seen. Similar results were obtained with partially purified preparations of the enzyme or with crude Renex-solubilized preparations from liver microsomes of rabbits either untreated or induced with phenobarbital, 5,6-benzoflavone, pregnenolone $16 \alpha$-carbonitrile, or Arochlor 1256 or 1260 . Such findings provided no indication for other immunologically cross-reactive forms of the reductase. These results are similar to those of Welton and Aust (44), who used antiserum to bromelain-solubilized rat liver reductase and detergent-solubilized microsomes from control rats or rats treated with phenobarbital or 3-methylcholanthrene.

In other experiments IgG from rabbits immunized against the purified rat liver reductase was incubated with solubilized microsomes from phenobarbital-induced rabbits, and the resulting precipitate was examined by SDS-polyacrylamide gel electrophoresis. As shown in Fig. 5, the precipitate contained a major band with the expected mobility of the reductase and only 


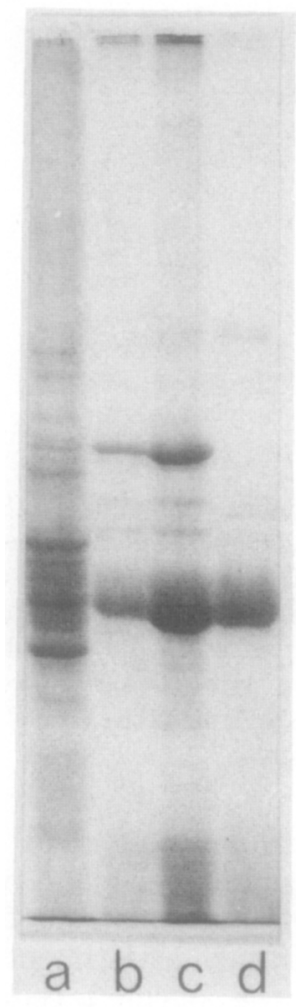

FIG. 5. SDS-polyacrylamide gel electrophoresis of reductase immunoprecipitate from rabbit liver microsomes. Phenobarbital-induced rabbit liver microsomes were solubilized by treatment with Renex 690 at a final concentration of $1.0 \%$, and the resulting preparation $(1.9 \mathrm{mg}$ of protein $/ \mathrm{ml})$ was incubated for $48 \mathrm{~h}$ at $4^{\circ} \mathrm{C}$ with a sufficient amount of rabbit anti-rat reductase IgG to inhibit half the cytochrome $c$ reduclase activity. Under these conditions greater than $90 \%$ of the reductase was precipitated. The precipitate was recovered by centrifugation, washed twice with the standard Tris buffer solution, and dissolved in the SDS- and $\beta$-mercaptoethanol-containing buffer routinely used for polyacrylamide gel electrophoresis. Samples submitted to electrophoresis were as follows: $a$, phenobarbital-induced microsomes $(10 \mu \mathrm{g}) ; b$, immunoprecipitate (approximately $1 \mu \mathrm{g}$ of reductase protein); $c$, immunoprecipitate (approximately $2 \mu \mathrm{g}$ of reductase protein); and $d, \operatorname{IgG}(2 \mu \mathrm{g}$ of protein).

a trace of two other bands typically seen with preparations known to have undergone slight proteolysis. The other major bands of lower molecular weight were those of the immunoglobulin light and heavy chains, as indicated in the control experiment $d$.

The amino acid composition of the rabbit
TABLE IV

Amino Acid Composition of Liver Microsomal NADPH-CYTOCHROME $P-450$ REDUCTASE ${ }^{a}$

\begin{tabular}{lcc} 
& \multicolumn{2}{c}{$\begin{array}{c}\text { Number of residues } \\
\text { per polypeptide }\end{array}$} \\
\cline { 2 - 3 } Amino acid & Rabbit enzyme & Rat enzyme \\
\hline CysO & & 7 \\
Asx & 10 & 62 \\
Glx & 64 & 82 \\
Thr & 82 & 36 \\
Ser & 33 & 45 \\
Pro & 41 & 31 \\
Gly & 29 & 48 \\
Ala & 44 & 50 \\
Val & 56 & 44 \\
Met & 44 & 16 \\
Ile & 14 & 27 \\
Leu & 21 & 62 \\
Tyr & 57 & 32 \\
Phe & 28 & 29 \\
Lys & 25 & 36 \\
His & 30 & 21 \\
Arg & 15 & 35 \\
Trp & 34 & 10 \\
Total & 6 & 673 \\
& 633 & \\
\hline
\end{tabular}

"The amino acid composition of the rat liver enzyme is taken from a previous publication (13).

liver reductase, calculated on the basis of a molecular weight of 74,000 , is given in Table IV, with that of the rat liver reductase included for comparison. The two proteins are similar in amino acid content, with the higher molecular weight rat enzyme containing larger amounts of a number of residues, especially leucine and isoleucine and the basic residues, lysine and histidine. Six tryptophan residues were determined after hydrolysis and seven by $N$-bromosuccinimide titrations in contrast to the values of 10 (13) and six ${ }^{5}$ reported for the rat protein. The presence of six to seven tryptophan residues is in close agreement with the observed ultraviolet spectrum. The value of 10 cysteic acid residues is higher than the six free sulfhydryl groups detected in other experiments by titration with D'NB in the presence of $4 \mathrm{M}$ guanidine; of these, only

${ }^{5} \mathrm{H}$. W. Strobel, personal communication. 
about 4.5 in the native enzyme reacted readily with DTNB. The half-cystine content of the rat reductase, determined as cysteic acid, has been reported as six to seven for the detergent-solubilized enzyme $(13,45)$ and six for the protease-solubilized form (46).

\section{Catalytic Activity of Purified Rabbit Liver Microsomal Reductase}

The turnover numbers of the purified reductase toward several acceptors at $30^{\circ} \mathrm{C}$ under optimal conditions are given in Table $\mathrm{V}$. Whereas the oxidase activity, or rate of NADPH oxidation by the enzyme in the presence of oxygen, is very low, the turnover number with cytochrome $c$ is slightly over 4000 under optimal conditions; the latter value would be only about 700 under the conditions which are optimal for the reconstituted enzyme system containing

TABLE V

Catalytic Activities of Purified Rabbit Liver Microsomal NADPH-CYTOCHROME

$P-450$ REDUCTASE ${ }^{a}$

\begin{tabular}{|c|c|c|}
\hline $\begin{array}{c}\text { Electron } \\
\text { acceptor } \\
\text { added }\end{array}$ & $\begin{array}{c}\text { Benzphetamine } \\
\text { present }\end{array}$ & $\begin{array}{c}\text { Observed } \\
\text { turnover } \\
\text { number }\end{array}$ \\
\hline Cytochrome $c$ & - & 4030 \\
\hline$P-450 \mathrm{LM}_{2}$ & + & 93 \\
\hline$P-450 \mathrm{LM}_{2}$ & - & 39 \\
\hline$P-450 \mathrm{LM}_{4}$ & + & 36 \\
\hline$P-450 \mathrm{LM}_{4}$ & - & 27 \\
\hline None & + & 3 \\
\hline None & - & \\
\hline
\end{tabular}

"The assays were carried out at $30^{\circ} \mathrm{C}$ as described in the text; dilauroyl-GPC was at a concentration of $50 \mu \mathrm{g} / \mathrm{ml}$ with $P-450 \mathrm{LM}_{2}$ and $20 \mu \mathrm{g} / \mathrm{ml}$ with $P-450 \mathrm{LM}_{4}$. The reaction rates were calculated from a series of experiments in which the reductase concentration (determined by the FMN content) was varied in the range from 0.05 to $0.25 \mu \mathrm{M}$. The values obtained in the assays with $P-450 \mathrm{LM}_{2}$ or $\mathrm{LM}_{4}$ were corrected for the rate observed in the absence of an added electron acceptor. The turnover numbers are expressed as moles of NADPH oxidized per minute per mole of reductase, except in the experiment with cytochrome $c$, where activity is expressed as moles of this acceptor reduced per minute per mole of reductase. $P-450 \mathrm{LM}_{4}$ from phenobarbital-induced animals was used in these experiments; highly similar results have been obtained using $P-450 \mathrm{LM}_{4}$ from 5,6-benzoflavone-induced animals.
$P-450$ cm. Thus, even in the presence of benzphetamine and dilauroyl-GPC, $P-450 \mathrm{LM}_{2}$ and $\mathbf{L M}_{4}$ are less effective electron acceptors than cytochrome $c$, as has been shown previously $(10,13)$. Upon the omission of benzphetamine, electron transfer to $P-450 \mathrm{LM}_{2}$ and $\mathrm{LM}_{4}$, as measured by the rate of NADPH oxidation, is decreased. Nordblom and Coon (47) have previously shown that hydrogen peroxide is formed in such a reconstituted system both in the presence and absence of substrate. These results obtained with rabbit reductase and the two forms of rabbit $P$-450LM are highly similar to those we have recently reported with the purified rat liver reductase and rabbit cytochromes (13), thereby indicating that the reductases are not species-specific.

\section{Absorption and CD Spectra of Purified Reductase in Various Oxidation- Reduction States}

This laboratory has recently reported the spectral characterization of the oxidationreduction states of purified rat liver microsomal reductase and shown that the airstable semiquinone form is a one-electronreduced species (13). This conclusion is in agreement with earlier studies of Iyanagi et al. (48) with the purified, trypsin-solubilized rabbit liver reductase. More recently, Vermilion and Coon (49) have provided evidence from studies with the FMN-depleted rat liver reductase that the low and high potential flavins are FAD and FMN, respectively. As shown in Fig. 6, photochemical reduction gives spectral changes of the same type as reported for the rat liver reductase (49). In the course of reduction, the oxidized enzyme (Spectrum $a$ ) proceeds through partially reduced forms (Spectra $b, c$, and $d$ ), finally giving the four-electron-reduced species (Spectrum $e$ ). NADP was then added in equimolar amount with respect to the starting enzyme, giving at equilibrium Spectrum $f$, which is predominantly that of the 3e-reduced species, with the flavin of lower potential in the semiquinone state $\left(\mathrm{FADH} \cdot-\mathrm{FMNH}_{2}\right)$. Finally, the cuvette was opened to air, and the resulting spectrum of the air-stable semiquinone (FADFMNH·) was recorded at about $30 \mathrm{~min}$. 


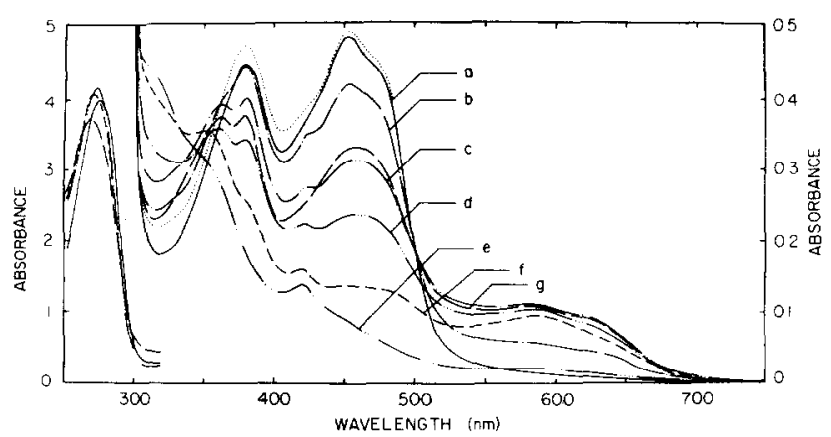

FiG. 6. Spectral changes upon photoreduction of reductase, followed by reoxidation by NADP and oxygen. A solution of $23.2 \mathrm{nmol}$ of reductase in $1.0 \mathrm{ml}$ of $0.05 \mathrm{M}$ Tris buffer, $\mathrm{pH} 7.7$, containing $10 \%$ glycerol and 5.0 mM EDTA, was made anaerobic, and the spectra were recorded as follows: $a$, starting reductase in fully oxidized state or, as shown by dotted line, after addition of $2.5 \mathrm{nmol}$ of deazaflavin (in $3 \mu \mathrm{l}$ of solution); $b-e$, after $8,16,26$, and $100 \mathrm{~min}$ of illumination, respectively; $f$, after $25 \mathrm{nmol}$ of NADP (in $10 \mu$ l of solution) were tipped in; and $g$, after the cuvette was opened to air. All spectra involving slow changes were recorded when disproportionation was complete. The spectra in the visible region were recorded at ten times greater sensitivity than in the ultraviolet region. The results were not corrected for the very small volume changes.

CD spectra recorded with some of the same reaction mixtures are shown in Fig. 7; the samples studied contained the fully oxidized enzyme and the 1e-, 3e-, and 4e-reduced forms for which absorption spectra (Curves $a, g, f$, and $e$, respectively) were presented in Fig. 6. To our knowledge, the only CD data reported previously on this enzyme are for the fully oxidized form of the reductase from rat liver (45). The oxidized form of the rabbit reductase has negative extrema at 440,350 , and $277 \mathrm{~nm}$, which correspond well to those reported for the rat liver enzyme. As shown in the figure, the various reduced forms have quite different CD spectra. The le-reduced species has strong negative bands at 470 (with a shoulder at higher wavelengths), 350 , and $274 \mathrm{~nm}$. The other neutral radical form, the 3e-reduced species, has negative bands at 432 and 360 $\mathrm{nm}$ with the absence of such a band in the ultraviolet region, except for a weak doublet
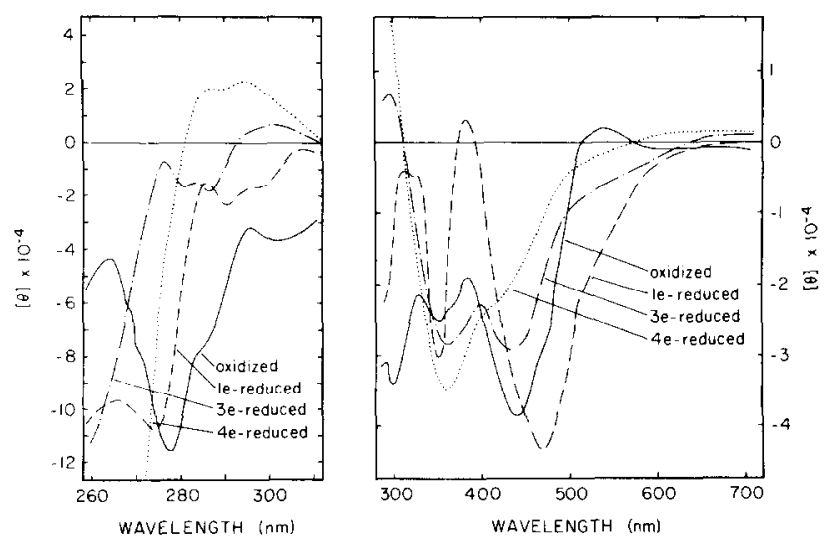

FIG. 7. CD spectra of reductase in various oxidation-reduction states. The CD spectra were recorded using the same reaction mixtures as in Fig. 6. The following experimental parameters were used for all the spectra: time constant, $4 \mathrm{~s}$; sensitivity, $0.5 \mathrm{~m}^{\circ} \mathrm{cm}^{-1}$; band pass, $2 \mathrm{~nm}$; chart speed, $0.5 \mathrm{~cm}$ $\min ^{-1}$; wavelength expansion, $10 \mathrm{~nm} \mathrm{~cm}^{-1}$ at 700 to $300 \mathrm{~nm}$ or $5 \mathrm{~nm} \mathrm{~cm} \mathrm{~cm}^{-1}$ at 300 to $250 \mathrm{~nm}$. The spectra represent two independent sequential scans. 
at 281 and $287 \mathrm{~nm}$. The fully reduced enzyme has a strong negative band at $360 \mathrm{~nm}$ with a shoulder at higher wavelength and a positive band at 294 and a shoulder at about $286 \mathrm{~nm}$. The results presented indicate that both the 1e- and 3e-reduced forms, which in the absorption spectra have maxima in the $600-\mathrm{nm}$ region, show no interesting features in this region of the CD spectrum. However, the environments of the two flavins appear to be quite different, as indicated by the other CD spectral features. In control experiments the CD spectra of NADP and NADPH were examined, and it was concluded that they do not contribute significantly in the free state to the results presented. Furthermore, the CD spectrum of the air-stable semiquinone was unchanged when the reaction mixture was extensively dialyzed against buffer.

As shown in Fig. 8, the oxidized form of the enzyme and the air-stable semiquinone form exhibit identical CD spectra in the far ultraviolet region with negative bands at

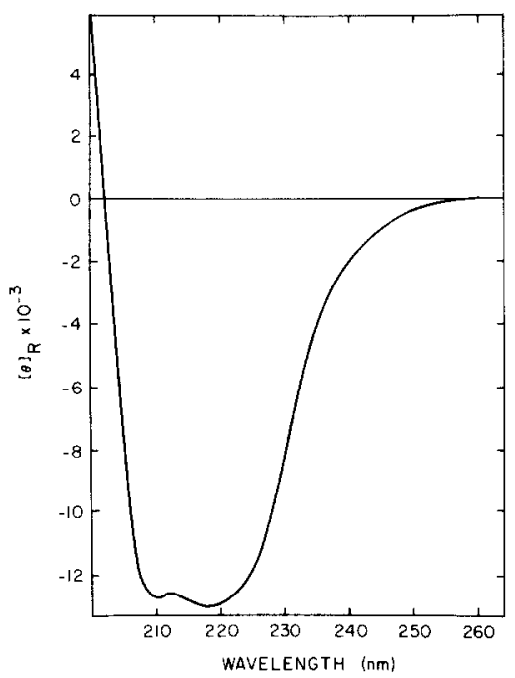

FIG. 8. Far ultraviolet CD spectrum of oxidized and le-reduced reductase. The air-stable semiquinone was produced by air oxidation of partially photoreduced reductase. The following experimental parameters were used: reductase concentration, $2.95 \mu \mathrm{M}$; path length, $2 \mathrm{~mm}$; time constant, $1 \mathrm{~s}$; band pass, $2 \mathrm{~nm}$; number of scans, 2 ; chart speed, $0.5 \mathrm{~cm} \mathrm{~min}^{-1}$; wavelength expansion, $2 \mathrm{~nm} \mathrm{~cm}^{-1}$. The presence of 633 amino acyl residues per molecule was taken into account in computing the mean residue ellipticity, $[\theta] R$.
219 and $210 \mathrm{~nm}$. Both forms have about $29 \%$ $\alpha$-helical content as estimated by the method of Greenfield and Fasman (50). A similar result has been reported for the oxidized form of the rat liver enzyme (45).

\section{DISCUSSION}

The purification procedure described provides a useful method for the isolation of rabbit liver microsomal NADPH-cytochrome $P-450$ reductase in conjunction with the two major forms of cytochrome $P-450, P-450 \mathrm{LM}_{2}$ and $P-450 \mathrm{LM}_{4}$. The isolated reductase appears to be homogeneous by SDS-polyacrylamide gel electrophoresis and other criteria and is similar in many of its properties to the reductase purified from rat liver microsomes in this and other laboratories. Evidence not presented in detail indicates that partially purified reductase preparations contain impurities which may be inhibitory to the usual catalytic activities of this enzyme in the reconstituted system and also influence the extent of hydrogen peroxide production (51). Accordingly, it is highly recommended that electrophoretically homogeneous enzyme preparations be used to obtain consistent results with the reconstituted enzyme system.

We have recently reported evidence for the possible occurrence of two forms of the reductase, from both rat and rabbit liver microsomes, differing significantly in their minimal molecular weights as judged by SDS-polyacrylamide gel electrophoresis (52). In the case of the rabbit liver reductase, the form routinely isolated has a minimal molecular weight of 74,000 ; the lower molecular weight forms sometimes seen, which retain cytochrome $c$-reducing activity and occasionally some cytochrome $P$-450-reducing activity, are attributed to shortening of the polypeptide chain by microsomal or bacterial proteases. The immunological and other properties of the reductase provide no evidence for multiple forms distinct in their pattern of induction, chemical properties, or substrate specificity. Such findings are in clear contrast to the evidence that $P-450 \mathrm{LM}$ occurs in several distinct forms $(14,15)$. However, in the case of the rat liver enzyme, two forms, both with minimal molec- 
ular weights significantly greater than protease-treated enzyme, may be resolved in purified preparations by a slight modification of the electrophoretic procedure described here (53). No evidence that these two forms differ in catalytic activity with $P$-450LM has yet been obtained, and the physiological significance of these results is not known. Blumer and Mieyal (54) have recently reported that hepatic microsomes from mice of different genetic strains exhibit activities with varying pyridine nucleotide concentrations which could be interpreted as evidence for two forms of the reductase.

Several recent investigations $(13,17,18$, $48,49)$ have described properties of the reductase attributable to differences in the environment of the two flavins. The absorption spectra presented above show that upon photoreduction the rabbit liver reductase behaves in the same manner as the rat liver reductase. Since the isoalloxazine ring is optically inactive, the CD bands are due to an asymmetric environment provided either by the optically active ribityl side chain or by the protein. The optical activity of a flavin is frequently increased 5 - to 20 -fold upon binding to a protein active site. Studies of Edmondson and Tollin (55) have shown that absorption and CD spectra of several FMN-containing proteins can be fitted by Gaussian curves corresponding to six vibronic bands. The optical activity of one or more of the contributing transitions may be enhanced in either a positive or negative direction by the protein environment. The shift from an absorbance maximum of $382 \mathrm{~nm}$ to a CD band at $350 \mathrm{~nm}$ for the oxidized form of the reductase suggests high optical activity of the $\pi \rightarrow \pi^{*}$ transition in the shorter-wavelength region. This blue shift of the CD band may also be attributed to an increase in the hydrophobicity of the flavin environment. The interpretation of the CD spectrum of the reductase in the oxidized form is complicated by the presence of both FAD and FMN. The CD spectra presented seem to fit closely neither those of dehydrogenases nor oxidases as described by Edmondson and Tollin (55) for these classes as differentiated by Massey et al. (56). On the other hand, the occurrence of two stable neutral flavin semiquinones and the low oxidase activity are consistent with the properties of other dehydrogenases. The CD spectra of semiquinone forms of proteinbound flavins have not been thoroughly studied, and we have made no attempt to interpret the specific features of the observed CD spectra for the 1e- and 3e-reduced forms of our enzyme. It may be mentioned, however, that the air-stable semiquinone has a CD spectrum atypical with respect to other flavoproteins. For example, the semiquinone of Shetna flavoprotein, which is also fairly air-stable, has a more pronounced CD doublet beyond $550 \mathrm{~nm}(55,57)$. The optical activities of the two semiquinone species of NADPH-cytochrome $P-450$ reductase differ considerably, indicating dissimilar protein environments of the two flavins, as one would expect from the known differences in oxidation-reduction potential, oxygen reactivity, and absorption spectra.

\section{ACKNOWLEDGMENTS}

We are grateful to Dr. Charles H. Williams, Jr., of this Department for the amino acid analyses, to Susan O. Krezoski for electrophoretic analyses and assistance in purification of the reductase, and to Sylvia B. Dahl and Steven G. Rothwell for the purification of cytochrome $P-450$.

\section{REFERENCES}

1. LU, A. Y. H., And Coon, M. J. (1968) J. Biol. Chem. 243, 1331-1332.

2. Coon, M. J., AND LU, A. Y. H. (1969) in Microsomes and Drug Oxidations (Gillette, J. R., Conney, A. H., Cosmides, G. J., Estabrook, R. W., Fouts, J. R., and Mannering, G. J., eds.), pp. 151-166, Academic Press, New York.

3. Lu, A. Y. H., Junk, K. W., AND Coon, M. J. (1969) J. Biol. Chem. 244, 3714-3721.

4. Williams, C. H., JR., AND Kamin, H. (1962) J. Biol. Chem. 237, 587-595.

5. Phillips, A. H., and Langdon, R. G. (1962) $J$. Biol. Chem. 237, 2652-2660.

6. Nishibayashi-Yamashita, H., aNd Sato, R. (1970) J. Biochem. (Tokyo) 67, 199-210.

7. Pederson, T. C., and Aust, S. D. (1972) Biochem. Biophys. Res. Commun. 48, 789-795.

8. CoOn, M. J., STrobel, H. W., ANd Boyer, R. F. (1973) Drug Metab. Dispos. 1, 92-97.

9. VAN DeR Hoeven, T. A., AND Coon, M. J. (1974) J. Biol. Chem. 249, 6302-6310.

10. Vermilion, J. L., AND Coon, M. J. (1974) Biochem. Biophys. Res. Commun. 60, 1315-1322. 
11. Yasukochi, Y., AND Masters, B. S. S. (1976) J. Biol. Chem. 251, 5337-5344.

12. Dignam, J. D., and Strobel, H. W. (1977) Biochemistry 16, 1116-1123.

13. Vermilion, J. L., AND COON, M. J. (1978) J. Biol. Chem. 253, 2694-2704.

14. Haugen, D. A., van der Hoeven, T. A., AND Cuon, M. J. (1975) J. Biol. Chem. 250, 35673570.

15. Haugen, D. A., ANd Coon, M. J. (1976) J. Biol. Chem. 251, 7929-7939.

16. French, J. S., Guengerich, F. P., and Coon, M. J. (1978) Fed. Proc. 37, 1568.

17. Iyanagi, T., ANAN, F. K., Imai, Y., and Mason, H. S. (1978) Biochemistry 17, 2224-2230.

18. Iyanagi, T., and Mason, H. S. (1973) Biochemistry 12, 2297-2308.

19. van der Hoeven, T. A., Haugen, D. A., and Coon, M. J. (1974) Biochem. Biophys. Res. Commun. 60, 569-575.

20. CoON, M. J., van DER HoEven, T. A., DAHL, S. B., AND Haugen, D. A. (1978) in Methods in Enzymology (Fleischer, S., and Packer, L., eds.), Vol. 52, pp. 109-117, Academic Press, New York.

21. Vermilion, J. L., AND Coon, M. J. (1976) in Flavins and Flavoproteins (Singer, T. P., ed.), pp. 674-678, Elsevier, Amsterdam.

22. LoWry, O. H., Rosebrough, N. J., FARR, A. L., AND RANDALl, R. J. (1951) J. Biol. Chem. 193, 265-275.

23. Dignam, J. D., and Strobel, H. W. (1975) Biochem. Biophys. Res. Commun. 63, 845-852.

24. Massey, V. (1959) Biochim. Biophys. Acta 34, $255-256$.

25. Poland, A. P., and Nebert, D. W. (1973) $J$. Pharmacol. Exp. Ther. 125, 105-110.

26. SPENCER, R. L., AND WOLd, F. (1969) Anal. Biochem. 32, 185-189.

27. Ellman, G. L. (1959) Arch. Biochem. Biophys. $82,70-77$.

28. Gething, M. J. H., AND Davidson, B. E. (1972) Eur. J. Biochem. 30, 352-353.

29. LiU, T.-Y., and Chang, Y. H. (1971) J. Biol. Chem. 246, 2842-2848.

30. Spande, T. F., ANd Witkop, B. (1967) in Methods in Enzymology (Hirs, C. H. W., ed.), Vol. 11, pp. 498-506, Academic Press, New York.

31. Guengerich, F. P., Ballou, D. P., and Coon, M. J. (1975) J. Biol. Chem. 250, 7405-7414.

32. Massey, V., and Hemmerich, P. (1977) J. Biol. Chem. 252, 5612-5614.

33. Laemmli, U. K. (1970) Nature (London) 227, $680-685$.

34. Faeder, E. J., ANd Siegel, L. M. (1973) Anal. Biochem. 53, 332-336.
35. Dubois, M., Gilles, K. A., Hamilton, J. K., Rebers, P. A., And Smith, F. (1956) Anal. Chem. 28, 350-356.

36. Masbach, E. H., Kalinsky, H. J., Halpern, E., and Kendall, F. E. (1954) Arch. Biochem. Biophys. 51, 402-410.

37. Chen, P. S., Toribara, T. Y., and Warner, H. (1956) Anal. Chem. 28, 1756-1758.

38. Bartlett, G. R. (1959) J. Biol. Chem. 234, 466468.

39. Garewal, H. S. (1973) Anal. Biochem. 54, 319-324.

40. Goldstern, S., ANd Blecher, M. (1975) Anal. Biochem. 64, 130-135.

41. Pederson, T. C., Buege, J. A., and Aust, S. D. (1973) J. Biol. Chem. 248, 7134-7141.

42. Omura, T., and Takesue, S. (1970) J. Biochem. (Tokyo) 67, 249-257.

43. Dean, W. L., and Coon, M. J. (1977) J. Biol. Chem. 252, 3255-3261.

44. Welton, A. F., And Aust, S. D. (1975) Biochem. Pharmacol. 24, 1641-1644.

45. Knapp, J. A., Dignam, J. D., and Strobel, H. W. (1977) J. Biol. Chem. 252, 437-443.

46. Masters, B. S. S., Kamin, H., Gibson, Q. H., and Williams, C. H., JR. (1965) J. Biol. Chem. 240, 921-931.

47. NoRdBlom, G. D., AND Coon, M. J. (1977) Arch. Biochem. Biophys. 180, 343-347.

48. Iyanagi, T., Makino, N., and Mason, H. S. (1974) Biochemistry 13, 1701-1710.

49. Vermilion, J. L., AND COON, M. J. (1978) J. Biol. Chem. 253, 8812-8819.

50. Greenfield, N., ANd Fasman, G. D. (1969) Biochemistry 8, 4108-4116.

51. Vatsis, K. P. (1978) Fed. Proc. 37, 1721.

52. Coon, M. J., Vermilion, J. L., Vatsis, K. P., French, J. S., DEAN, W. L., AND HaUgen, D. A. (1977) in Drug Metabolism Concepts (Jerina, D. M., ed.), American Chemical Society Symposium Series, No. 44, pp. 46-71.

53. Vermilion, J. L. (1976) Doctoral Thesis, The University of Michigan.

54. Blumer, J. L., AND Mieyal, J. J. (1978) J. Biol. Chem. 253, 1159-1166.

55. Edmondson, D. E., AND Tollin, G. (1971) Biochemistry 10, 113-123.

56. Massey, V., Múller, F., Feldberg, R., Schuman, M., Sullivan, P. A., Howell, L. G., Mayhew, S. G., Matthews, R. A., and Foust, G. P. (1969) J. Biol. Chem. 244, 3999-4006.

57. Edmondsun, D. E., ANd Tollin, G. (1971) Biochemistry 10, 133-145. 